\title{
Response of Ocypode quadrata to storm waves on an urbanized sandy beach
}

\author{
Fernanda Ramos Fernandes de Oliveira ${ }^{1,2,3 *}$, Leonardo Querobim Yokoyama' ${ }^{10}$
}

\author{
1 Universidade Federal de São Paulo - Programa de Pós-Graduação em Análise Ambiental Integrada (Rua São Nicolau, 210 - Diadema \\ - 09913-030 - SP - Brazil) \\ ${ }^{2}$ Universidade Federal de São Paulo - Departamento de Ciências do Mar - Laboratório de Ecologia e Gestão Costeira, (Rua Carvalho \\ de Mendonça, 144 - Santos - 11070-100 - SP - Brazil) \\ ${ }^{3}$ Universidade Federal do ABC - Programa de Pós-Graduação em Evolução e Diversidade (Av. dos Estados, 5001 - Bairro Bangu - Santo André \\ 09210-580 - SP - Brazil)
}

*Corresponding author: fernanda.rfo@hotmail.com

\section{ABSTRACT}

Extreme climate events cause major disturbances to the fauna of sandy beaches. For abiotic-controlled species, storm waves play a significant role in controlling populations. Considering the projected increase in the frequency of extreme climate events and the consequential influence on benthic macrofauna, there is a need to adjust the time-scale of observations. In this context, we conducted weekly monitoring of the ghost crab Ocypode quadrata on an urbanized sandy beach in southeast Brazil to evaluate the effect of storm waves on population dynamics. The effect of storm wave events was not as strong as expected, but two of the 8 registered storm events provoked an increase in density of $O$. quadrata. Although not significant, after events $4-5$, the population suffered a decrease in density and burrows were concentrated in the upper supralittoral, probably because of contiguous effect of habitat reduction by trampling and the storm waves. It is probable that the combination of storm wave events in conjunction with urbanization could have prevented the population recovery by reducing the overall recruitment or even causing mortality or migration towards safer areas. Multi-factor approaches are needed to better understand the dynamics of $O$. quadrata in urbanized beaches, however, our study showed that weekly monitoring allowed us to record subtle variations in population dynamics that would go unregistered with other approaches but might reveal long-term changes.

Descriptors: Burrow resetting, Climate change, Ghost crab, Human impacts, Monitoring.

\section{INTRODUCTION}

Coastal urbanization is one of the major threats to sandy beaches (Schlacher et al., 2007). This dynamic and fragile ecosystem has been degraded due to disorderly coastal occupation and tourism (Blankensteyn, 2006), with negative consequences for biodiversity (Scherner et al., 2013). The construction of artificial structures to support tourism (e.g. groins and piers) modifies local hydrodynamic

Submitted: 13-May-2020

Approved: 21-March-2021

Associate Editor: Abilio Soares-Gomes

(C) 2021 The authors. This is an open access article distributed under the terms of the Creative Commons license. regimes, promotes beach accretion and/or erosion, and consequently, alters the benthic community (Walker et al., 2008). Another result of coastal urbanization is the adoption of management actions such as beach cleaning and nourishment, which alters the characteristics of the sediment, with major consequences for the biota (Peterson et al., 2000; Hobbs et al., 2008). Furthermore, climate changes will affect factors such as temperature, winds, and tides, which are some of the natural drivers of sandy beach fauna populations; as a consequence sandy beach communities will be exposed to increased risk (Lucrezi \& Schlacher, 2009). Species inhabiting sandy beaches sensitive to anthropogenic and climatic impacts are 
especially affected by extreme events, responding to these disturbances in different ways.

The Atlantic ghost crab Ocypode quadrata (Fabricius, 1787) is a common sandy beach crustacean that normally occupies the supralittoral and upper intertidal regions (Lucrezi \& Schlacher, 2014). Regarding its ecology, populations are mainly regulated by grain size, slope (Pombo et al., 2017b) and tide regime (Pombo et al., 2017a). Among benthic macrofauna species, it is one of the most affected by coastal urbanization. The abundance of $O$. quadrata is negatively correlated to the urbanization levels of the beach (see Schlacher et al., 2016), with records of changes to their age structure (Ocana et al., 2016), behavior (Gül \& Griffen, 2019a) and zonation (Araujo et al., 2008). The species is also vulnerable to loss of habitat due to dune and vegetation replacement by artificial structures (Alberto \& Fontoura, 1999), which can cause shifts in their spatial distribution and abundance (Schlacher et al., 2016). Wind and wave action can also affect burrow longevity (Gül \& Griffen, 2019a) by obstructing the entrance with sand or destroying it during flood. Therefore, populations of $O$. quadrata on urbanized beaches are much more prone to decrease due to singular extreme events, such as storm waves.

The increase in frequency and intensity of storm waves are consequences of global climatic changes (McCarthy et al., 2001). These extreme events, like storm surges, have a direct impact on the composition and abundance of benthic macrofauna in sandy beaches (Machado et al., 2016; Costa et al., 2019). For O. quadrata, hurricanes (Gül \& Griffen, 2019a) and storm surges (Hobbs et al., 2008) affect abundance, age structure and zonation. Although less extreme disturbances, such as storm waves, have different impacts on populations of $O$. quadrata, the combination of storm waves and urbanization is still highly negative for the species (Gül \& Griffen, 2019b; Machado et al., 2019). Taking into account the predicted increase in the frequency of these extreme events, monitoring studies can provide essential information regarding how macrobenthic species, like O. quadrata, respond to the altered climatic conditions.

Given the unpredictability of future weather conditions for some areas, monitoring studies need to consider the time between observations, in order to not lose relevant information on the dynamics of populations, especially those already constricted by anthropogenic pressure on urbanized beaches.
Although the relationship between Ocypode and coastal urbanization is widely explored in the literature (Araujo et al., 2008; Lucrezi \& Schlacher, 2009; Machado et al., 2016; Gül \& Griffen, 2019a), the sampling periodicity in ecological studies varies from a few days (Barros, 2001; Neves \& Benvenutti, 2006; Pombo et al., 2017a) to weeks (Hobbs et al., 2008; Lucrezi \& Schlacher, 2009), months (Alberto \& Fontoura, 1999; Negreiros-Fransozo et al., 2002; Branco et al., 2010; Pombo \& Turra, 2017) or seasons (Blankensteyn, 2006; Pombo et al., 2017b). However, the studies with more frequent periodicity (days and weeks) had short durations, varying from a month to one year. To our understanding, no previous study used a long-term dataset (collected over a year) in the form of weekly observations to analyze the population dynamics of $O$. quadrata in an urbanized beach. This approach has the potential to provide a unique record regarding the effect of storm waves on populations already living at the extremes of their tolerance. In this context, we performed continuous weekly monitoring of a population of O. quadrata in an urbanized beach to understand how storm waves influence its abundance and spatial distribution.

\section{METHODS}

\section{STUDY AREA}

The weekly monitoring of Ocypode quadrata occurred at Satélite Beach ( $24^{\circ} 10^{\prime} 43.534^{\prime \prime}$ S; $46^{\circ} 461^{\prime}$ 24.202" W), located in the city of Itanhaém, on the south coast of the State of São Paulo, southeast Brazil (Fig. 1). Satélite Beach is a stretch of sand within a $40 \mathrm{~km}$ beach arc, with the Itanhaém river estuary opening approximately $2 \mathrm{~km}$ to the south of the study area. The morphodynamic characteristics of the site is a high energy dissipative sandy beach, with intermediate tendencies, but because of constant erosion it can change to an intermediate state (Souza, 2012). Beach width was approximately $90 \mathrm{~m}$ and the supralitoral consisted of small frontal dunes covered by a mixture of local vegetation and grass. There was no construction on the backshore within 150 meters of the sampling area; however, there was a sea wall from a recreational club to the north and several houses to the south. This beach is preferentially used by tourists and local residents during the summer holidays. 


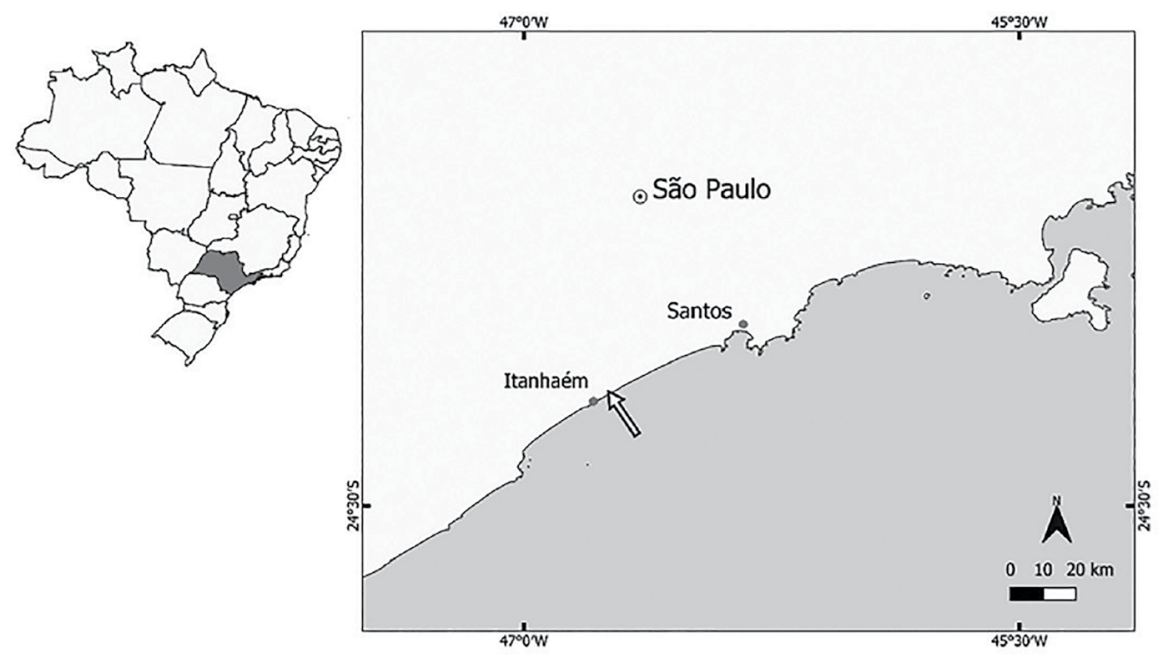

Figure 1. Map of Brazil showing the location of the state of São Paulo and of Satélite Beach (arrow).

\section{SAMPLING}

Sampling occurred weekly between September 5th 2016 and January 2nd 2018 ( $N=57$ continuous observation events) using methodology adapted from Borzone et al. (2015). Initially, a sampling area of $100 \mathrm{~m}^{2}$ was established between the upper intertidal zone and the frontal dunes. In this area, we randomly assigned three transects equally separated by $3 \mathrm{~m}$ and perpendicular to the water line. Samples per transect consisted of 7 juxtaposed quadrats of $4 \mathrm{~m}^{2}$ (total sampling area $=28 \mathrm{~m}^{2}$ ).

The abundance of $O$. quadrata and its burrow dimensions (diameter and depth) were assessed by the burrow resetting method (Pombo \& Turra, 2019). This technique consists in covering the entrance of the burrows with sand to assess occupation rate. Caution was taken to not completely fill the burrows with sand to avoid harming the crabs. This species maintains their burrows (Gül \& Griffen, 2019a) and must emerge to feed, thus allowing us to register active individuals. This methodology was divided in two phases: (1) Resetting: initially, data on diameter, depth and location of every burrow were registered; depth was measured using a graduated rod. After this procedure, each burrow was identified with a marker and covered with a fine layer of sand. (2): Verification: after a minimum interval of $12 \mathrm{hs}$ (Pombo \& Turra, 2019), we verified which burrows were opened. Due to the nocturnal habits of $O$. quadrata in the area, resetting was done in the afternoon ( $4 \mathrm{pm})$, and verification in the morning ( 8am), at low tide and during periods of low trampling. During the summer holidays (December 2016/2017 and January 2017/2018), to avoid the effect of greater abundance of tourists, resetting was performed later in the afternoon ( 7pm) and the verification was done the next day earlier in the morning, always respecting the minimum interval of $12 \mathrm{hs}$ among phases. Data on burrow size (diameter and depth) was not sampled between September and late December 2016.

The data used to evaluate the influence of abiotic factors on the abundance of $O$. quadrata during the storm wave events was obtained from different sources for each sampling date. Local air temperature and precipitation were obtained from Accuweather and Centro Nacional de Monitoramento e Alertas de Desastres Naturais (CEMADEN), respectively. Precipitation data obtained from CEMADEN originated from an automatic pluviometer located near the sampling station. Nocturnal luminosity data was obtained from Tábua de Marés (2020) as established by Fortaleza et al. (2019). Nocturnal luminosity was calculated by averaging values from 3 consecutive days: (1) the day of the sampling and the days (2) before and (3) after the sampling, in order to cover the entire period of the experiment, from the resetting phase to the verification. Temperature data consisted of the mean temperature of the sampling day. Average wave height and wind velocity were obtained from the Centro de Hidrografia da Marinha - Marinha do 
Brasil. The oceanographic data was collected by a buoy located at the coordinates $25^{\circ} 26^{\prime} 37^{\prime} \mathrm{S} ; 45^{\circ} 02^{\prime} 17^{\prime \prime}$ W. Because of buoy failures and maintenance periods (9th April 2017 - 6th June 2017; 15th August 2017 - 9th November 2017), we were only able to obtain data for 36 of the 57 weeks.

\section{Data ANALYsis}

To identify storm wave events, we used the pattern verified by Machado et al. (2016), where sampling days with a register of waves higher than $2 \mathrm{~m}$ were considered storm wave events as characterized by the National Institute for Space Research (Instituto Nacional de Pesquisas Espaciais - INPE). This data was used to identify 8 storm surge events during 2016 and 2017.

Density was calculated using the number of open burrows of $O$. quadrata in the verification period and the total sampling area $\left(28 \mathrm{~m}^{2}\right)$ of each transect. Occupation rate was obtained by dividing the number of open burrows by the total counted in the resetting period. Burrows were divided into three categories: those with diameters up to $14 \mathrm{~mm}$ were classified as recruits, diameters between 14 and $20 \mathrm{~mm}$ as juveniles and diameters $>20 \mathrm{~mm}$ as adults (Alberto \& Fontoura, 1999).

To evaluate the effect of pulse events we used a modified version of the Before-After-Control Impact (BACl) design (Underwood, 1994). For each storm wave event $(\mathrm{N}=8)$, we applied the same design with three treatments: (1) 4-10 days before the storm (Before), (2) the day of the event (Event), and (3) 6-10 days after the event (After). As data for the abiotic variables was obtained only at the end of the experiment, there was a variation in the number of days before and after each storm event. An ANOVA was used to evaluate possible variations in density, size of the burrows (diameter and depth), and occupation rate between the three treatments. In cases of significant differences, a Tukey t-test was applied for pairwise comparisons between before, during and after events. The across-shore distribution of the ghost crabs during storm wave events was compared between weeks using kite graphs. The fourth and fifth storm wave events occurred in subsequent weeks, thus we opted to test them together, using (Before) a week before the fourth event, (Event) both storm wave events and (After) the week after the fifth, resulting in a design with 4 treatments.
A Multiple Linear Regression analysis was applied to evaluate which abiotic variables (air temperature, precipitation, average wave height, wind velocity, and nocturnal luminosity) were responsible for variations in the abundance of $O$. quadrata during the storm wave events, i.e., considering the $\mathrm{BACl}$ designs for each of the storm waves. Independent climate variables were tested for collinearity (Table S1, Suppl. Mat.) and missing data were excluded from the analysis. Outliers were checked using residuals and models were constructed by means of a Forward Stepwise method. Statistical analyses were done using the Statistica v13.0 (StatSoft) and PAST software (Hammer et al., 2001), considering significance levels of 0.05 .

\section{RESULTS}

Over the 17 months, we identified 8 storm wave events (SWE) at Satélite Beach: 3 occurred during the last three months of 2016 and 5 were distributed throughout 2017 (Fig. 2). Weekly densities of $O$. quadrata varied from 0 to 0.063 inds/ $\mathrm{m}^{2}$ (Fig. 2), with a mean of $0.016 \pm 0.017$ inds/ $\mathrm{m}^{2}$. High densities were observed at the beginning of the monitoring, on September 05th and October 17th 2016 (Fig. 2); a decrease in density occurred after SWE 4 and 5 and, with the exception of an increase on October 10th 2017, densities remained low $\left(<0.002\right.$ inds $\left./ \mathrm{m}^{2}\right)$ throughout 2017. The population structure of O. quadrata, based on the burrow diameter, was composed of $69.6 \%$ adults (mean diameter of $28.49 \mathrm{~mm} \pm 7.78$ ), $23.9 \%$ juveniles (mean diameter of $17.71 \mathrm{~mm} \pm$ 2.19 ) and $6.5 \%$ recruits (mean diameter of $11.15 \pm$ 2.08). Juveniles and adults together represented 93.5\% of the individuals in the population, with higher recruitment periods being registered only on March 20th 2017.

Storm wave events had little influence on the population parameters of $O$. quadrata, with significant differences being registered in density and burrow depth (Table 1). At SWE1 and SWE7, density increased three- and sevenfold, respectively, after the events (Table 1). Burrow depth remained without great changes over the study period, with the exception during the events SWE4-5, when it increased from 0 to $24.28 \mathrm{~cm}$. No differences were found for burrow diameter or occupation rate. Despite these results, the across-shore distribution of $O$. quadrata 


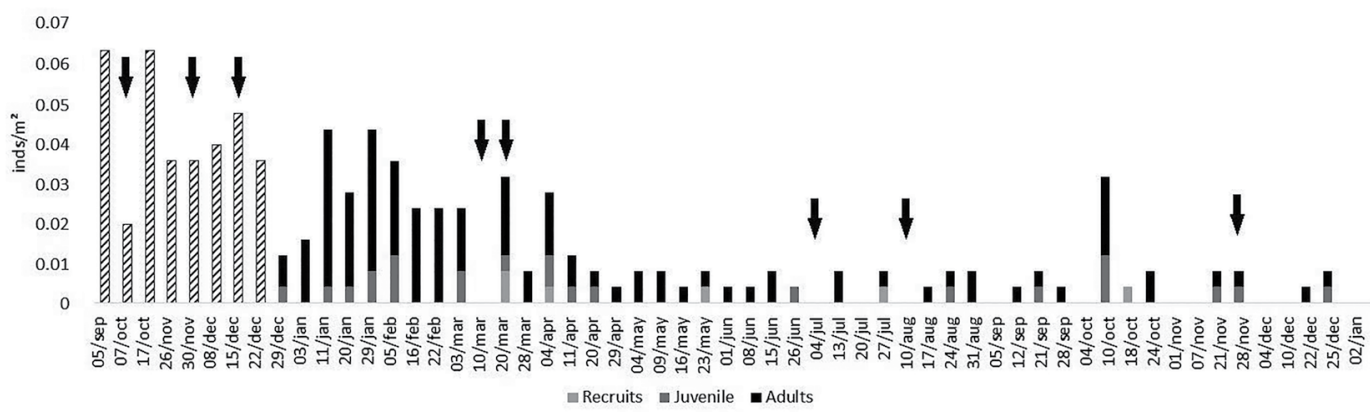

Figure 2. Density per $\mathrm{m}^{2}$ and age structure of the population of 0 . quadrata per week. Density per $\mathrm{m}^{2}: 0-0.63$ inds $/ \mathrm{m}^{2} ;$ Age structure: $0-14 \mathrm{~mm}$ recruits, $14-20 \mathrm{~mm}$ juveniles and $>20 \mathrm{~mm}$ adults. Hatch pattern: weeks when no age differentiation was included. Arrows indicate the sampling days right after storm wave events.

changed during SWE, with individuals occupying the upper supralittoral after storm wave events, especially from SWE 1 and SWE 4 and 5 (Fig. 3). During the other events of 2017 , the population was restricted to the supralittoral.

The abundance of $O$. quadrata among SWE was significantly determined by precipitation and wind velocity $\left(\mathrm{F}_{2,47}\right)=5.494 ; p<0.01 ; \mathrm{R}^{2}=$ 0.186 ). Although the model (Abundance $=1.484+$ $0.091 *$ Precipitation $-0.106 *$ Wind velocity) was significant, it explained only $19 \%$ of the variance in the abundance of $O$. quadrata, with precipitation having a bigger contribution $(\beta=0.374 ; \mathrm{t}=2.798$; $p<0.01)$ than wind velocity $(\beta=-0.145 ; \mathrm{t}=-1.080$; $p>0.05$ ). Abundance of the ghost crab during storm wave events was higher when precipitation increased (Fig. 4), while wind velocity had the opposite effect, reducing the number of burrows of O. quadrata at Satélite Beach.

\section{DISCUSSION}

Climate change and urbanization are two major threats to sandy beach health and to the maintenance of biodiversity. In this context, populations at urbanized beaches face multiple stressors such as waves, predation by shorebirds, hawks, burrowing owls (Lucrezi \& Schlacher, 2014) or even dogs, and anthropogenic impacts, which can be potentialized under a future scenario of climate change. Contrary to our hypothesis, the effect of storm waves on the population of Ocypode quadrata at the urbanized Satélite Beach was less intense than expected. Density of crabs increased after 2 of the 8 events, with no distinguishable effect on burrow size and occupation rate. On the other hand, a strong reduction in population density after SWE 4-5 may have potentially reduced local populations to minimum levels due to massive mortality or migration, which could have interfered with our subsequent results. Interestingly, the weekly monitoring allowed us to record subtle variations in population dynamics and local beach morphology, revealing potential long-term effects of extreme events.

Density of $O$. quadrata was generally not affected by storm waves, and was higher one week after SWE1 and SWE7, similar to the pattern registered for Excirolana braziliensis on two different beaches in Southeastern Brazil (Machado et al., 2016). Ocypode quadrata showed a high resilience to SWE at the beginning of our study, with high densities (0.063 inds/ $\mathrm{m}^{2}$ ) during all periods after the events. However, the increase in density after SWE7 was superficial and the population never completely recovered from the decline caused by SWE 4-5. Contrary to our expectations, it remained below 0.008 inds $/ \mathrm{m}^{2}$ during the remainder of the study, with no signs of recovery, even with an elevation in the temperature. The absence of recovery of $O$. quadrata may be a consequence of reduced larval production and dispersion from adjacent areas because of weather severity, leading to unsuccessful recruitment. Negreiros-Fransozo et al. (2002) related delayed larval releases by ovigerous females of $O$. quadrata to a decrease of water temperature by the South Atlantic Central Waters at a Southeastern Brazilian beach. Regarding our results, during a period of 6 months, the area suffered 5 storm wave events, with two of them occurring sequentially over a 10-day period. These recurrent impacts, coupled with the fragility of the population at an urbanized location (Gül \& Griffen, 2019a; Machado et al., 2019), may have triggered a weak but constant 
Table 1. Mean \pm standard deviation of ecological parameters measured before, during and after the storm wave events. A: Sample at the week before the event (BEFORE); B: Sample at the day of event (EVENT); C: Sample at the week after the event (AFTER). T-test results are only for storm wave 1. $p$ values in red indicate significant differences in the ecological parameter.

\begin{tabular}{|c|c|c|c|c|c|c|}
\hline & BEFORE & EVENT & AFTER & $t / F$ & \multirow[t]{2}{*}{$\mathbf{p}$} & \multirow[t]{2}{*}{$\begin{array}{c}\text { tukey's } \\
\text { pairwase }\end{array}$} \\
\hline & A & B & C & & & \\
\hline \multicolumn{7}{|l|}{ Storm wave 1} \\
\hline Density $\left(m^{2}\right)$ & & $0.020 \pm 0.007$ & $0.063 \pm 0.018$ & 4.303 & 0.032 & \\
\hline Depth (cm) & & $43.833 \pm 14.495$ & $27.729 \pm 3.296$ & 4.303 & 0.275 & \\
\hline Ocupation rate (\%) & & $0.417 \pm 0.220$ & $0.545 \pm 0.079$ & 4.303 & 0.507 & \\
\hline \multicolumn{7}{|l|}{ Storm wave 2} \\
\hline Density $\left(\mathrm{m}^{2}\right)$ & $0.036 \pm 0.031$ & $0.036 \pm 0.012$ & $0.040 \pm 0.018$ & 0.036 & 0.965 & $A=B=C$ \\
\hline Depth $(\mathrm{cm})$ & $53.610 \pm 33.752$ & $26.250 \pm 17.206$ & $41.723 \pm 10.357$ & 10.980 & 0.392 & $A=B=C$ \\
\hline Ocupation rate (\%) & $0.667 \pm 0.333$ & $0.556 \pm 0.096$ & $0.292 \pm 0.054$ & 2.708 & 0.145 & $A=B=C$ \\
\hline \multicolumn{7}{|l|}{ Storm wave 3} \\
\hline Density $\left(m^{2}\right)$ & $0.040 \pm 0.018$ & $0.048 \pm 0.021$ & $0.036 \pm 0.024$ & 0.250 & 0.787 & $A=B=C$ \\
\hline Depth (cm) & $41.723 \pm 10.357$ & $37.500 \pm 14.756$ & $13.917 \pm 15.177$ & 3.651 & 0.092 & $A=B=C$ \\
\hline Ocupation rate (\%) & $0.292 \pm 0.054$ & $0.522 \pm 0.191$ & $0.300 \pm 0.072$ & 3.565 & 0.095 & $\mathrm{~A}=\mathrm{B}=\mathrm{C}$ \\
\hline \multicolumn{7}{|l|}{ Storm wave 4 and 5} \\
\hline Density $\left(m^{2}\right)$ & $0.024 \pm 0.012$ & $0 ; 0.032 \pm 0.08$ & $0.008 \pm 0.014$ & 3.745 & 0.060 & $\mathrm{~A}=\mathrm{B} 1=\mathrm{B} 2=\mathrm{C}$ \\
\hline Depth (cm) & $12.223 \pm 4.809$ & $0 ; 24.278 \pm 4.820$ & $13.333 \pm 23.094$ & 5.303 & 0.026 & $B 1 \neq B 2=A=C$ \\
\hline Ocupation rate (\%) & $0.476 \pm 0.041$ & $0 ; 0.667 \pm 0.153$ & $0.400 \pm 0.385$ & 1.837 & 0.219 & $\mathrm{~A}=\mathrm{B} 1=\mathrm{B} 2=\mathrm{C}$ \\
\hline Diameter (mm) & $25.890 \pm 5.852$ & $0 ; 24.361 \pm 0.511$ & $17.000 \pm 24.042$ & 2.040 & 0.187 & $\mathrm{~A}=\mathrm{B} 1=\mathrm{B} 2=\mathrm{C}$ \\
\hline \multicolumn{7}{|l|}{ Storm wave 6} \\
\hline Density $\left(\mathrm{m}^{2}\right)$ & $0.004 \pm 0.007$ & $0.004 \pm 0.007$ & $0.028 \pm 0.007$ & 1.374 & 0.323 & $A=B=C$ \\
\hline Depth (cm) & $13.333 \pm 23.094$ & $6.667 \pm 11.547$ & $30.000 \pm 36.056$ & 1.109 & 0.389 & $\mathrm{~A}=\mathrm{B}=\mathrm{C}$ \\
\hline Ocupation rate (\%) & $0.500 \pm 05.77$ & $0.500 \pm 0.577$ & $1.000 \pm 0.577$ & 1.485 & 0.299 & $\mathrm{~A}=\mathrm{B}=\mathrm{C}$ \\
\hline Diameter (mm) & $11.000 \pm 8.602$ & $9.000 \pm 12.728$ & $22.333 \pm 15.839$ & 2.651 & 0.150 & $A=B=C$ \\
\hline \multicolumn{7}{|l|}{ Storm wave 7} \\
\hline Density $\left(m^{2}\right)$ & $0.008 \pm 0.007$ & $0.004 \pm 0.007$ & $0.028 \pm 0.007$ & 10.330 & 0.011 & $A=B \neq C$ \\
\hline Depth (cm) & $20.333 \pm 22.811$ & $6.667 \pm 11.547$ & $39.500 \pm 15.596$ & 2.730 & 0.144 & $A=B=C$ \\
\hline Ocupation rate (\%) & $0.667 \pm 0.577$ & $0.500 \pm 0.577$ & $1.000 \pm 0$ & 1.515 & 0.293 & $A=B=C$ \\
\hline Diameter (mm) & $11.000 \pm 8.602$ & $9.000 \pm 12.728$ & $19.778 \pm 3.612$ & 0.792 & 0.495 & $A=B=C$ \\
\hline \multicolumn{7}{|l|}{ Storm wave 8} \\
\hline Density $\left(m^{2}\right)$ & $0.008 \pm 0.014$ & $0.008 \pm 0.014$ & 0.000 & 0.459 & 0.653 & $A=B=C$ \\
\hline Depth (cm) & $33.333 \pm 57.735$ & $13.833 \pm 23.960$ & 0.000 & 0.646 & 0.557 & $A=B=C$ \\
\hline Ocupation rate (\%) & $0.110 \pm 0.191$ & $0.182 \pm 0.385$ & 0.000 & 0.586 & 0.586 & $A=B=C$ \\
\hline Diameter $(\mathrm{mm})$ & $7.167 \pm 10.135$ & $7.167 \pm 10.135$ & 0.000 & 0.500 & 0.630 & $A=B=C$ \\
\hline
\end{tabular}

decrease. Also, this could have led to mortality or even migration of the individuals to more appropriate locations that offered better conditions, such as lower anthropogenic pressures and more protection from storm waves. Hobbs et al. (2008) cited migration of individuals to regions that offer more protection against both anthropogenic and natural impacts.
A major component of the establishment and persistence of $O$. quadrata is burrow integrity, which is positively correlated to sediment stability (Schlacher et al., 2016) and negatively to coastal erosion. The latter could reduce density values (Hobbs et al., 2008) if it provokes a substantial change in the beach morphology. In the first week of March 2017, we noticed 


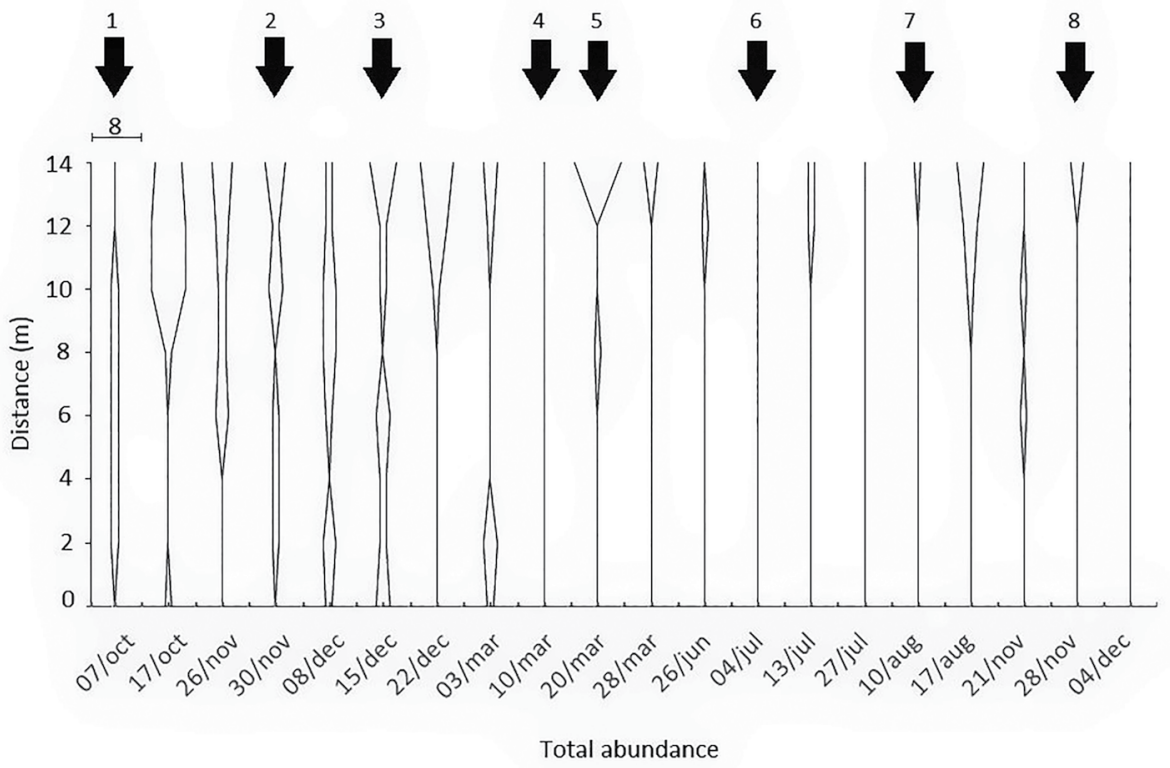

Figure 3. Across-shore distribution of Ocypode quadrata during the $\mathrm{BACl}$ pulse events. Arrows indicate the sampling day right after storm wave events.

signs of erosion process at the upper supralittoral, with no effect on the morphology of the area and in the population, which is corroborated by the increase in densities after SWE5. By late March 2017, part of the frontal dunes collapsed, where most of the burrows were located (Fig. 3), and from this moment on densities were strongly reduced. High intensity storm waves or storm surges are capable of provoking coastal erosion, but this impact could also be a consequence of intensive trampling. There is no data to reveal which one, if not both, was the cause for the collapse of the upper supralittoral, but the impact on the population of $O$. quadrata is certain.

The across-shore distribution at Satélite Beach varied, with burrows being registered from the intertidal to upper supralittoral zone until SWE4-5. After this, the distribution was restricted to supralittoral and upper supralittoral in most weeks. Although this could be a consequence of crabs searching for a higher protection from predators (Branco et al., 2010), it is also possible that individuals could have temporarily migrated into dunes and other protected areas of the shore during storm waves (Gül \& Griffen, 2019a; Machado et al., 2019). Furthermore, the occurrence of frequent storm waves associated with the anthropogenic impacts characteristic of an urbanized beach such as trampling, could hinder the return of individuals to the area they previously occupied (Machado et al., 2019). This was reflected in the distribution of the different age classes, with adults being registered over most of the weeks, opposite of the pattern registered by Gül \& Griffen (2019b). Even though there were more adults than juveniles throughout monitoring, juvenile crabs were present; if not in the next week after the events, they were perceived after two weeks. Recruits, although in lower numbers, were also present year-round, confirming the continuous reproduction observed for this species in southeastern Brazil (Alberto \& Fontoura, 1999; Lucrezi \& Schlacher, 2014). Nonetheless, the reduction in the densities by the end of March 2017 had a strong impact in the population dynamics of the species. From this moment, recruitment seems to have occurred in pulses, and this could be a consequence of the local restriction to settlement of the larvae in the study area. Another hypothesis is that the frontal dune collapse reduced the amount of available area for burrow construction. After March 2017, adults were predominant from dunes to intertidal zones while juveniles and recruits occurred only in the intertidal.

Precipitation and wind velocity were the only abiotic variables with power to explain the variance in the abundance of $O$. quadrata. Precipitation had a positive relation with abundance and wind velocity a negative, but contrary to the benthic macrofauna evaluated by Machado et al. (2016), 

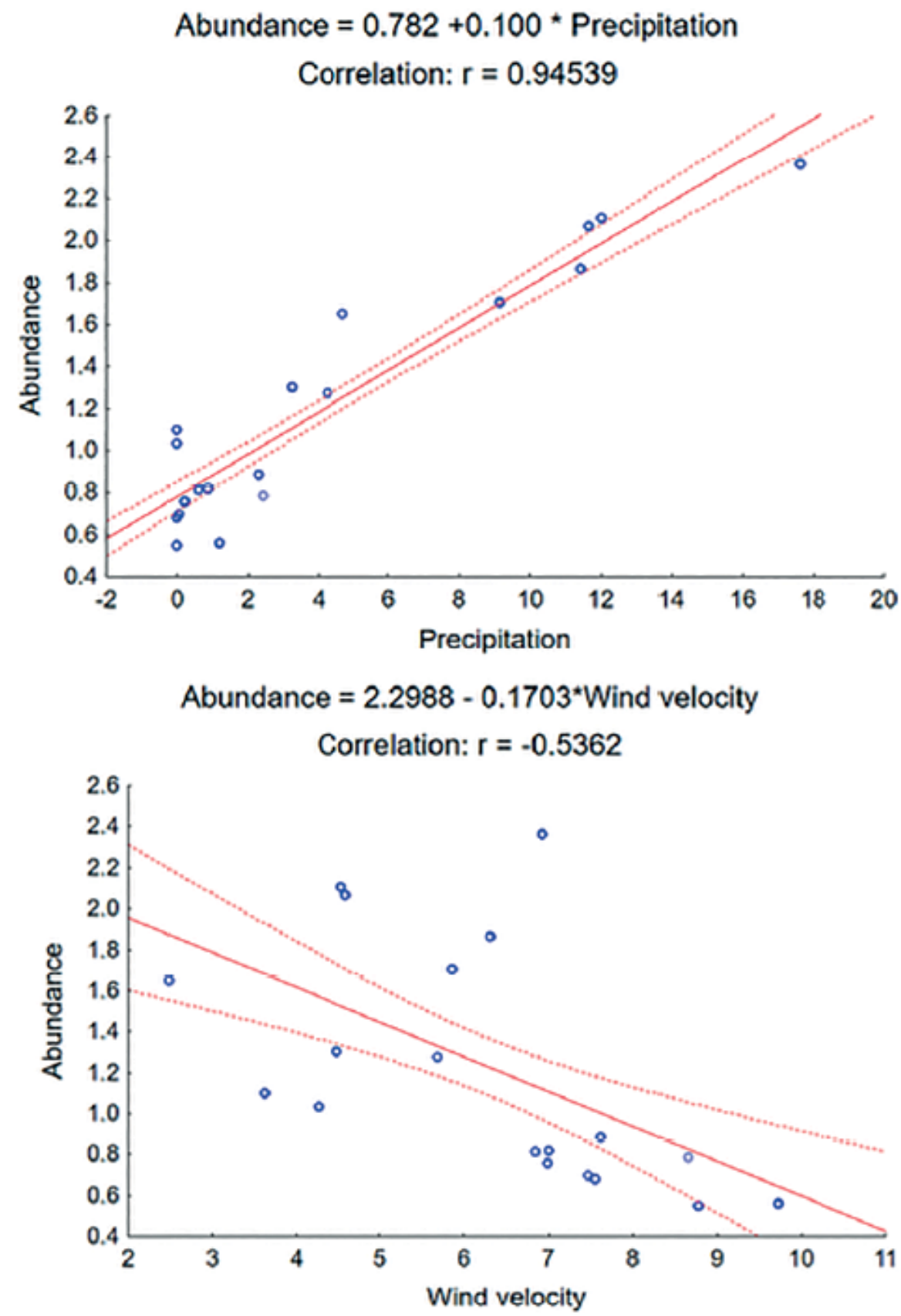

Figure 4. Correlation between the abundance of Ocypode quadrata and the precipitation and wind velocity. Data considered in the correlations are only for the storm wave events. Red line represents the estimated equation; red dashed lines represent the $95 \%$ confidence interval.

there was no relation to wave height. However, our model with negative correlation to wind velocity and absence of a relation to storm waves is very similar to the results obtained by Machado et al. (2019) for O. quadrata in Rio de Janeiro, southeast Brazil. Despite the significant relation between these parameters, they only explained $27 \%$ of the variance in the data, which indicates that (1) other variables not measured could be influencing the burrow abundance in our study area and/or; (2) association between abiotic variables, storm waves and anthropogenic impacts affected 
the population in a way that we were unable to perceive. Storm waves are a stochastic event that impacted sandy beach macrofauna (Machado et al., 2016), with smaller populations having greater vulnerability to this type of perturbation (Gilpin \& Soulé, 1986). Furthermore, the study area was disturbed by constant erosion and high levels of trampling and beach cleaning, especially at the supralittoral. These processes modify the morphology of the beach and the food availability by revolving and filtering the sediment (Brown \& McLachlan, 2002) or extracting the first layers of the sediment, which normally contains most of the fauna and flora (Defeo et al., 2009). Thus, in our study, multiple pulse disturbances seem to have overlapped possible effects of precipitation and wind velocity. Higher precipitation reduces sediment micro-relief, particularly in highly trampled areas and high wind velocity closes the burrows, explaining the positive and negative relationships, respectively.

Populations of $O$. quadrata in urbanized beaches could be impacted by both anthropogenic and abiotic variables and its interaction makes the relation between ecological and natural/anthropogenic variables hard to predict or evaluate. Although some studies testify that extreme climatic events in urbanized beaches impact sandy beach macrofauna (Machado et al., 2016; 2019; Corte et al., 2017), it is very difficult to dissociate climatic from anthropogenic variables to determine which one is affecting the population. In the present study, we observed that storm waves associated with urbanization changed the dynamics of the physical environment and prevented the population from recovering to its previous state at the beginning of the monitoring. Despite the limitations in our study (beach replication, for example), it was clear that without the weekly monitoring we would not perceive the differences in the intensity of the modifying factors. Our contributions increase the knowledge on the factors that could impact $O$. quadrata on urbanized beaches and, therefore, can influence both its abundance and distributions. Future studies should focus on analyzing how an interplay of both anthropogenic factors (such as trampling) and environmental drivers (such as precipitation and wave action) (Barros, 2001) can affect populations of $O$. quadrata.

\section{ACKNOWLEDGMENTS}

The authors would like to thank the Coordenação de Aperfeiçoamento de Pessoal de Nível Superior (CAPES) for providing the scholarship grant to FRFO. We thank Elizabete Alves Ramos de Oliveira for helping with field sampling and two anonymous reviewers that greatly contributed to the improvement of the manuscript. The English revision of this manuscript was done by Yasmina Shah Esmaeili.

\section{AUTHOR CONTRIBUTIONS}

F.R.F.O.: Conceptualization, Formal analysis, Investigation, Methodology, Writing - original draft, Writing - review \& editing.

L.Q.Y.: Conceptualization, Formal analysis, Investigation, Methodology, Writing - original draft, Writing - review \& editing.

\section{REFERENCES}

ALBERTO, R. M. F \& FONTOURA, N. F. 1999. Distribuição e estrutura etária de Ocypode quadrata (Fabricius, 1787) (Crustacea, Decapoda, Ocypodidae) em praia arenosa do litoral sul do Brasil. Revista Brasileira de Biologia, 59(1), 95-108.

ARAUJO, C. C., ROSA, D. M. \& FERNANDES, J. M. 2008. Densidade e distribuição espacial do caranguejo Ocypode quadrata (Fabricius, 1787) (Crustacea, Ocypodidae) em três praias arenosas do Espírito Santo. Revista Biotemas, 21(4),73-80.

BARROS, F. 2001. Ghost crabs as a tool for rapid assessment of human impacts on exposed sandy beaches. Biological Conservation, 97(3), 399-404.

BLANKENSTEYN, A. 2006. O uso do caranguejo maria-farinha Ocypode quadrata (Fabricius) (Crustacea, Ocypodidae) como indicador de impactos antropogênicos em praias arenosas da Ilha de Santa Catarina, Santa Catarina, Brasil. Revista Brasileira de Zoologia, 23(3), 870-76.

BORZONE, C. A., ROSA, L. C., GUILHERME, P. D. B. \& VIEIRA, J. V. 2015. Monitoramento de populações de Ocypode quadrata. In: TURRA, A. \& DENAIR, M. R. (orgs.). Protocolos para o Monitoramento de Habitats Bentônicos Costeiros - Rebentos (Rede de Monitoramento de Habitat Bentônicos Costeiros). São Paulo: Universidade de São Paulo, pp. 244-249.

BRANCO, J. O., HILLSHEIM, J. C., FRACASSO, H. A. A., CHRISTOFFERSEN, M. L. \& EVANGELISTA, C. L. 2010. Bioecology of the ghost crab Ocypode quadrata (Fabricius, 1787) (Crustacea: Brachyura) compared with other intertidal crabs in the southwestern Atlantic. Journal of Shellfish Research, 29(2), 503-512.

BROWN, A. C. \& MCLACHLAN, A. 2002. Sandy shore ecosystems and the threats facing them: some predictions for the year 2025. Environmental Conservation, 29(1), 62-77.

CORTE, G. N., SCHLACHER, T. A., CHECON, H. H., BARBOZA, C. A. M., SIEGLE, E., COLEMAN, R. A. \& AMARAL, A. C. Z. 2017. Storm effects on intertidal invertebrates: increased beta diversity of few individuals and species. PeerJ, 5, e3360. 
COSTA, L. L., MACHADO P. M. \& ZALMON I. R. 2019. Do natural disturbances have significant effects on sandy beach macrofauna of Southeastern Brazil? Zoologia, 36, e29814.

DEFEO, O., MCLACHLAN, A., SCHOEMANN, D. S., SCHLACHER, T. A., DUGAN, J., JONES, A., LASTRA, M. \& SCARPINI, F. 2009. Threats to sandy beach ecosystems: a review. Estuarine, Coastal and Shelf Science, 81(1), 1-12.

FORTALEZA, M. O., GIRÃO, M. M. L., FRANKLIN JUNIOR, W., LIMA, J. P., ROCHA-BARREIRA, C. A. 2019. Which moon phase do we find more ghosts? Effects of the lunar cycle on the ghost crab Ocypode quadrata (Fabricius, 1787). Arquivos de Ciências do Mar, 52, 85-97.

GILPIN, M. E. \& SOULÉ, M. E. 1986. Minimum viable populations: processes of species extinction. In: SOULÉ, M. E. (ed.). Conservation biology: the science of scarcity and diversity. Suderland: Sinauer.

GÜL, M. R. \& GRIFFEN, B. D. 2019a. Burrowing behavior and burrowing energetics of a bioindicator under human disturbance. Ecology and Evolution, 9(24), 142205-14216.

GÜL, M. R. \& GRIFFEN, B. D. 2019b. Combined impacts of natural and anthropogenic disturbances on the bioindicator Ocypode quadrata (Fabricius, 1787). Journal of Experimental Marine Biology and Ecology, 519, 151185.

HAMMER, Ø., HARPER, D. A. T. \& RYAN, P. D. 2001. Past: Paleontological statistics software package for education and data analysis [online]. Palaeontologia Electronica, 4(1), 1-9. Available at: http://palaeo-electronica.org/2001_1/past/ issue1_01.htm [Accessed: 20 February 2021].

HOBBS, C. H., LANDRY, C. B. \& PERRY, J. E. 2008. Assessing anthropogenic and natural impacts on ghost crabs (Ocypode quadrata) at Cape Hatteral National Seashore, North Carolina. Journal of Coastal Research, 24(6), 1450-8.

LUCREZI, S. \& SCHLACHER, T. A. 2014. The ecology of ghost crabs. Oceanography and Marine Biology: An Annual Review, 52, 201-56.

LUCREZI, S., SCHLACHER, T. A. \& WALKER, S. 2009. Monitoring human impacts on sandy shore ecosystems: a test of ghost crabs (Ocypode spp.) as biological indicators on an urban beach. Environmental, monitoring and assessment, 152, 413424.

MACHADO, P. M., COSTA, L. L., SUCIU, M. C., TAVARES, D. C. \& ZALMON, I. R. 2016. Extreme storm wave influence on sandy beach macrofauna with distinct human pressures. Marine Pollution Bulletin, 107(1), 25-135.

MACHADO P. M., TAVARES D. C. \& ZALMON I. R. 2019. Synergistic effect of extreme climatic events and urbanization on population density of the ghost crab Ocypode quadrata (Fabricius, 1787). Marine Ecology, 40(2), e12525.

MCCARTHY, J. J., CANZIANI, O. F., LEARY, N. A., DOKKEN, D. J. \& WHITE, K. S. 2001. Climate Change 2001, impacts, adaptation, and vulnerability. Cambridge: Intergovernmental Panel on Climate Change/Cambridge University Press.

NEGREIROS-FRANSOZO, M. L., FRANSOZO, A. \& BERTINI, G. 2002. Reproductive cycle and recruitment period of Ocypode quadrata (Decapoda, Ocypodidae) at a sandy beach in southeastern Brazil. Journal of Crustacean Biology, 22(1), $157-161$
NEVES, F. M. \& BEMVENUTTI, C. E. 2006. The ghost crab Ocypode quadrata (Fabricius, 1787) as a potential indicator of anthropic impact along the Rio Grande do Sul coast, Brazil. Biological Conservation, 133(4), 431-435.

OCANA, F. A., JESUS-NAVARRE, A., JESUS-CARRILLO, R. M. \& OLIVA-RIVERA, J. J. 2016. Efectos del disturbio humano sobre la dinamica poblacional de Ocypode quadrata (Decapoda: Ocypodidae) en playas del Caribe Mexicano. Revista de Biologia Tropical, 64(4), 1625-1641.

PETERSON, C. H., HICKERSON, D. H. \& JOHNSON, G. G. 2000. Short-term consequences of nourishment and bulldozing on the dominant large invertebrates of a sandy beach. Journal of Coastal Research, 16(2), 368-378.

POMBO, M., CAMPAGNOLI, M., CASTILHO-MARTINS, E.A. \& TURRA. A. 2017a. Continuous, video-recording assessment of daily activity cycle of the ghost crab Ocypode quadrata Fabricius, 1787 (Brachyura: Ocypodidae) in southeastern Brazil. Journal of Crustacean Biology, 1-7.

POMBO, M., OLIVEIRA, A. L., XAVIER, L. Y., SIEGLE, E. \& TURRA, A. $2017 \mathrm{~b}$. Natural drivers of distribution of ghost crabs Ocypode quadrata and the implications of estimates from burrows. Marine ecology progress series, 565, 131-147.

POMBO, M. \& TURRA, A. 2017. Variation in the body growth parameters of the ghost crab Ocypode quadrata from morphodynamically distinct sandy beaches. Brazilian Journal of Oceanography, 65(4), 656-665.

POMBO, M. \& TURRA, A. 2019. The burrow resetting method, an easy and effective approach to improve indirect ghost-crab population assessments. Ecological Indicators, 104, 422-428.

SCHERNER, F., HORTA, P. A., OLIVEIRA, E. C, SIMONASSI, J. C., HALL-SPENCER, J. M., CHOW, F., NUNES, J. M. C. \& PEREIRA, S. M. B. 2013. Coastal urbanization leads to remarkable seaweed species loss and community shifts along the SW Atlantic. Marine Pollution Bulletin, 76(1-2), 106-15.

SCHLACHER, T. A., DUGAN, J., SCHOEMAN, D. S., LASTRA, M., JONES, A., SCAPINI, F., MCLACHLAN, A. \& DEFEO, O. 2007. Sandy beaches at the brink. Diversity and Distributions, 13(5), 556-560.

SCHLACHER, T. A., LUCREZI, S., CONNOLLY, R. M., PETERSON, C. H., GILBY, B. L., MASLO, B., OLDS, A. D., WALKER, S. J., LEON, J. X., HUIJBERS, C. M., WESTON, M. A., TURRA, A., HYNDES, G. A., HOLT, R. A. \& SCHOEMAN, D. S. 2016. Human threats to sandy beaches: a meta-analysis of ghost crabs illustrates global anthropogenic impacts. Estuarine, Coastal and Shelf Science, 169, 56-73.

SOUZA, C. R. G. 2012. Praias arenosas oceânicas do estado de São Paulo (Brasil): síntese dos conhecimentos sobre morfodinâmica, sedimentologia, transporte costeiro e erosão costeira. Revista do Departamento de Geografia, spe v., 207-371.

TÁBUA DE MARÉS E SOLUNARES. 2020. Previsão e pescaria - Santos [online]. Santos: Tábua de Marés. Available at: https://tabuademares.com/br/so-paulo/santos [Accessed: $20^{\text {th }}$ February 2021].

UNDERWOOD, A. J. 1994. On beyond BACl: sampling designs that might reliably detect environmental disturbances. Ecological Applications, 4(1), 3-15.

WALKER, S. J., SCHLACHER, T. A. \& THOMPSON, L. M. C. 2008. Habitat modification in a dynamic environment: the influence of a small artificial groyne on macrofaunal assemblages of a sandy beach. Estuarine, Coastal and ShelfScience, 79(1), 24-34. 


\section{SUPPLEMENTARY MATERIAL}

Table S1. Correlation matrix of environmental variables.

\begin{tabular}{|c|c|c|c|c|c|}
\hline Variables & Wave height & Pluviometry & Air temperature & Wind velocity & $\begin{array}{l}\text { Nocturnal } \\
\text { luminosity }\end{array}$ \\
\hline Wave height & 1.000000 & & & & \\
\hline Pluviometry & 0.134596 & 1.000000 & & & \\
\hline Air temperature & -0.317949 & -0.021182 & 1.000000 & & \\
\hline Wind velocity & 0.340498 & -0.231844 & -0.166374 & 1.000000 & \\
\hline Nocturnal luminosity & 0.251785 & -0.422207 & -0.069378 & 0.194556 & 1.000000 \\
\hline
\end{tabular}

